\title{
Shakespeare and the Irish Writer
}

\section{Sophie Chiari}

\section{(2) OpenEdition}

1 Journals

\section{Electronic version}

URL: http://journals.openedition.org/etudesirlandaises/2519

DOI: 10.4000/etudesirlandaises.2519

ISSN: 2259-8863

\section{Publisher}

Presses universitaires de Caen

\section{Printed version}

Date of publication: 30 December 2011

Number of pages: 189-192

ISSN: 0183-973X

\section{Electronic reference}

Sophie Chiari, « Shakespeare and the Irish Writer », Études irlandaises [Online], 36-2 | 2011, Online since 30 September 2011, connection on 21 September 2020. URL : http://journals.openedition.org/ etudesirlandaises/2519; DOI : https://doi.org/10.4000/etudesirlandaises.2519

This text was automatically generated on 21 September 2020.

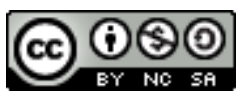

Études irlandaises est mise à disposition selon les termes de la Licence Creative Commons Attribution - Pas d'Utilisation Commerciale - Partage dans les Mêmes Conditions 4.0 International. 


\title{
Shakespeare and the Irish Writer
}

\author{
Sophie Chiari
}

\section{REFERENCES}

Janet Clare and Stephen O' Neill (eds.), Shakespeare and the Irish Writer, University College Dublin Press, 2010, 201 p., ISBN 978-1-906359-39-3

1 In the wake of his Staging Ireland: Representations in Shakespeare and Renaissance Drama (2007), Stephen O'Neill, assisted by Janet Clare, tackles the vast topic of the ambivalent reception of Shakespeare in Ireland in a collection of twelve homogeneous and interrelated essays which focus on the unexpected links between the Elizabethan playwright and Ireland. Here, the spotlight falls on a cast of late nineteenth- and twentieth-century Irish writers characterized by their engagement with Shakespeare's plays and poems. If a writer as emblematic as Bernard Shaw (1856-1950) remains famous for having coined the word "bardolatry" in order to designate the generalized admiration towards the playwright, Irish writers, as noted by Clare and O'Neill in their introduction, have also been keen on subverting or misquoting Shakespeare, which testifies to the fact that "not all Irish writers have shared Shaw's admiration of Shakespeare's word music" (11).

2 This is clearly demonstrated by Philip Edwards who opens the volume with a general chapter on "Shakespeare and the Politics of the Irish Revival". Edwards aptly reminds us that a certain kind of political resistance to the "flagship of English literature" (25) actually took place among some of the Irish writers particularly involved in the nationalist movement at the turn of the $20^{\text {th }}$ century. Brian Cosgrove gives fresh impetus to Edwards' analysis by throwing a new light on Yeats and Dowden in chapter 2. In "Shakespeare, Douglas Hyde, 1916", Andrew Murphy leaves Yeats and Dowden well behind in order to give a detailed account of the three hundredth anniversary of Shakespeare's death which, in 1916, somewhat unfortunately coincided with Easter Sunday. On that occasion, Israel Gollancz unveiled the publication of his volume entitled A Book of Homage to Shakespeare. The book included an odd contribution, which 
presented a disturbing Irish poem questioning imperial hegemony and its English translation in parallel, surprisingly accommodating given the harshness of the original. Murphy proceeds with the analysis of the fascinating double life of this text written by Douglas Hyde who, as the founder of the Gaelic League, had first proposed his poem in Irish.

Matthew Creasy delves further into Shakespeare's reception in Ireland in the years before independence by reaffirming the "divided loyalties" (80) that Shakespeare elicited. After a brief look at Stephen Dedalus's theory of Hamlet, he then focuses on "Hamlet among the Celts" by John Swift, who specialized in Shakespearean parody, and who wrote for The Leader, the journal of D. P. Moran's Irish Ireland movement. While, in a learned piece of scholarship entitled "Shakespeare and Company", Declan Kiberd pays attention to Joyce's vision of Hamlet in Ulysses, and he notably explains why "Stephen identifies Shakespeare not with his greatest creation Prince Hamlet, but rather with the ghost of the dead king, whose impossible part he bravely played" (97).

Chapter 7, one of the most compelling for Shakespearian critics, dwells on George Bernard Shaw, who settled in London in the mid-1870s as a young man and spent a large part of his career reassessing Shakespeare's works. Indeed, Cary DiPietro reminds us that as early as 1898 , the young author decided to write Caesar and Cleopatra, whose plot is supposed to unravel just before the events taking place in Julius Caesar (1599). The Irish playwright had actually used Shakespeare to provide his readers with his own understanding of historical change as well as with a critical view of British literature, while emphasizing his own complex identity, that of an Irish expatriate.

5 The volume's chronology is then somewhat disturbed by an essay devoted to Oscar Wilde, born in Dublin in 1854. "However imaginatively secure Wilde might have felt within the language and landscape of Shakespeare's creation". Interestingly enough, Doody insists on the fact that Wilde was actually the precursor of Harold Bloom's theory according to which Falstaff and Hamlet are nothing less than "the invention of the human". Richard Meek continues on Wilde and his stimulating essay shows how some of Wilde's works enact the "ambiguous processes of literary and non-literary influences" (148). Oddly enough, Wilde kept asserting his Irishness while simultaneously claiming his admiration for Shakespeare. In 1892, fearing that his French play Salome might be banned in England.

6 In chapter 10, Heather Ingman demonstrates the full power of Shakespearian references throughout Elizabeth Bowen's works. Caliban's ghost haunts a short story such as "Sunday Afternoon" (1941), for instance. However, Ingman mainly focuses on a novel entitled The Last September (1929) - actually a picture of the Anglo-Irish gentry to emphasize Bowen's use of Twelfth Night (1601). David Wheatley, in the next essay of the volume, proceeds to analyze how Samuel Beckett used King Lear in Endgame (1957), a play originally written in French, and much concerned with nothingness, thus echoing Shakespeare's numerous "nothings" in his 1607 tragedy. In both plays, there is no hope of redemption, and the future looks bleak. The last chapter sets Shakespeare's works in the context of the contrasting cultures of the late twentieth century. Indeed, Helen Heusner Lojek concludes the volume with a chapter devoted to Frank McGuinness's links with the Bard, fully revealed by Mutabilitie (1997), a work curiously constrained by the audience's lack of fluency in Irish, but which nonetheless defends Irish traditions by staging an imaginary encounter between Shakespeare and Spenser in Ireland. 
7 Shakespeare and the Irish Writer includes a useful Index, but lacks a recapitulative bibliography which could have been most helpful for students and scholars alike. It should also be said that readers who look for detailed literary analyses of Shakespeare's works may be put off by the volume under review. Even though references to his plays are numerous, long citations are sparse.

8 However, those interested in the reception of the Bard's writings will be delighted by the book's richness and its variety of critical approaches. This carefully edited volume, which takes into account both nationalist and revisionist readings of Irish history, very skillfully deals with the question of English imperialism in a Catholic Ireland battling against Protestantism. In this context, it attempts to explain how William Shakespeare - whose only Irish character, a quarrelsome captain called Macmorris (Henry V), comically criticized his own nation - became paradoxically politicized by committed Irish artists in order to promote their cause. Moreover, all of the essays keep addressing the Irish writer's "anxiety of influence" when faced with the work of his/ her great predecessor, while they provide new insights into the fields of shakespeare and Irish studies. For all these reasons, the editors of the volume should be warmly praised.

\section{AUTHORS}

SOPHIE CHIARI

Université d'Aix-Marseille 